\title{
A DEFECT IN THE METABOLISM OF TYROSINE AND PHENYLAL- ANINE IN PREMATURE INFANTS. II. SPONTANEOUS OCCURRENCE AND ERADICATION BY VITAMIN C ${ }^{1,2}$
}

\author{
By S. Z. LEVINE, HARRY H. GORDON AND ELEANOR MARPLES \\ (From the New York Hospital and the Department of Pediatrics, Cornell University \\ Medical College, New York City)
}

(Received for publication October 24, 1940)

In the preceding paper (1) an account was given of an aberration in the metabolism of tyrosine and phenylalanine in premature infants characterized by the urinary excretion of 1 -p-hydroxyphenyllactic and $p$-hydroxyphenylpyruvic acids. Data on the isolation, identification and properties of these intermediary metabolites and the chemical methods employed for their quantitative assay were presented. Earlier studies (2) had shown an irregular exhibition of the defect in premature infants fed high protein diets and this finding, together with observed variations in the magnitude and duration of excretion of abnormal metabolites in infants receiving equivalent protein intakes, pointed to the importance of other dietary factors besides the level of ingested protein. Later studies (3) demonstrated the curative properties of vitamin C.

This paper presents data which establish the following facts: (1) the prevalence and persistence of the defect in premature infants fed high protein diets ( 5 grams or more per $\mathrm{kgm}$.) devoid of vitamin $\mathrm{C} ;(2)$ its absence in full term infants receiving similar diets; (3) its production in the latter infants by feeding the pure amino acids, 1-tyrosine or d,1-phenylalanine; (4) the specificity of vitamin $\mathrm{C}$ in preventing and eradicating the defect.

\section{METHODS}

Subjects. Thirteen healthy male premature infants ranging in age from 6 to 31 days, and weighing from 1.49 to $2.22 \mathrm{kgm}$. at the start of observations, were studied on diets of vitamin C-free cow's milk throughout periods of from 4 to 69 days for a total of 378 days. The infants resided in a constant temperature and humidity room and were under the supervision of 4 spe-

\footnotetext{
1 Presented in part at the meeting of the American Pediatric Society at Skytop, Pa., on May 3, 1940.

2 Assistance in this work was given by the Children's Bureau, United States Department of Labor.
}

cially trained nurses whose sole duties consisted of the preparation of the diets, collection of the urine and general care of the infants. Only one or occasionally 2 infants were observed at one time.

Twelve male full term infants ranging in age from 9 to 195 days, and weighing from 2.78 to $6.88 \mathrm{kgm}$. at the start of observations, were studied on similar diets in periods of from 1 to 28 days for a total of 83 days. The infants had completely recovered from the conditions for which they had been admitted to the hospital (respiratory infection, bronchopneumonia, hemorrhagic disease of the newborn, malnutrition, hypertrophic pyloric stenosis), and they were thriving during the periods of observation. Two of the full term infants who were studied on the basal diets of cow's milk were also studied following the ingestion of phenylalanine or tyrosine.

Diets. The basal diets consisted of dilutions of cow's milk supplemented with dextrimaltose or cane sugar. The total fluid and caloric intakes averaged $150 \mathrm{cc}$. and 120 calories per $\mathrm{kgm}$. per 24 hours and were adequate to permit satisfactory weight gains. Protein supplied from 15 to 20 per cent, ${ }^{3}$ butter fat or olive oil (olac) from 20 to 40 per cent, and carbohydrate the remaining 40 to 60 per cent of the calories. Twenty drops of a vitamin $\mathrm{A}$ and $\mathrm{D}$ concentrate (percomorph oil) were given daily. No vitamin $\mathrm{C}$ was added to the diets and analyses of the milk preparations showed the absence of ascorbic acid (4). Foreperiods of constant diet of at least 3, and usually many more days, preceded the onset of observations.

Supplements. The effect of vitamin $\mathrm{C}$ on the excretion of hydroxyphenyl compounds was determined in 10 premature and 2 full term infants, none of whom had previously received vitamin $C$ in their diets. After the abnormal metabolites had appeared in the urine and were present in large amounts, vitamin $\mathrm{C}$ was given by mouth or parenterally in daily amounts ranging from 10 to $500 \mathrm{mgm}$. 1-ascorbic acid to the point of eradication of these substances from the urine. Besides these studies

3 Aliquot samples of the pooled milks were analyzed for nitrogen (Kjeldahl). The protein intake (nitrogen $X$ 6.25) approximated 5 to 6 grams per kgm. per 24 hours and the calculated content of phenylalanine plus tyrosine (expressed as tyrosine) (1) averaged $500 \mathrm{mgm}$. per kgm. The following preparations of cow's milk were used : powdered whole milk, powdered half-skimmed milk (alacta), olac and half-skimmed olac. 
of the therapeutic action of vitamin C, its prophylactic effect was also noted in an additional 11 premature and 4 full term infants by the inclusion in their basal diets of supplements of vitamin C (10 or $20 \mathrm{mgm}$. 1-ascorbic acid daily) for a varying number of days prior to observations.

In order to demonstrate the specificity of the curative properties of vitamin C, a number of infants who were excreting large amounts of hydroxyphenyl compounds during foreperiods of basal diets of cow's milk were given the following supplements, either singly or in combination and in high dosage: $d$-isoascorbic acid, thiamine, nicotinic acid, riboflavin, pyridoxine (vitamin $B_{6}$ ), vitamin $H$ (biotin), pantothenic acid, choline chloride, liver extract, yeast powder, rice polishings, atocopherol and adrenal cortical extract (cortate).4

Urine. A detailed description of the method for collecting urine separately from feces in premature infants was given in previous papers (5). Urine was collected quantitatively from all of the infants throughout observations and analyzed at the end of each 24-hour period for the normal urinary constituents listed in the preceding paper (1), for total hydroxyphenyl compounds (tyrosine, $p$-hydroxyphenyllactic and $p$-hydroxyphenylpyruvic acids, expressed as tyrosine) $(6,7)$, and for the keto acid alone ( $p$-hydroxyphenylpyruvic acid) (7) by the methods there outlined. The difference between the total tyrosine equivalent and the keto acid afforded a quantitative estimate of $p$-hydroxyphenyllactic acid (1).

Blood. Determinations of plasma ascorbic acid were made in a number of the infants 5 by the method of Mindlin and Butler (8). Roentgenograms of the long bones were taken at frequent intervals on 10 premature infants receiving the basal diets devoid of vitamin $C$.

\section{RESULTS}

Spontaneous excretion of hydroxyphenyl compounds by premature infants fed vitamin $C$-free cow's milk and the effect of vitamin $C$. In Table I, the urinary excretion of total hydroxyphenyl compounds (expressed as tyrosine) and of $p$ hydroxyphenylpyruvic acid is presented for 13 premature infants receiving basal diets of vitamin C-free cow's milk, containing, with one exception (F. J. L.), from 700 to $900 \mathrm{mgm}$. of nitrogen per $\mathrm{kgm}$. per day (4.4 to 5.6 grams of protein). All of the infants had been observed since birth and at no time prior to the onset of observations

1 The authors wish to thank Drs. R. R. Sealock, P. György, V. du Vigneaud, C. P. Rhoads, Mead Johnson Co., the Merck Chemical Co. and Eli Lilly and Co. for supplying generous amounts of one or more of these products.

5 The authors are indebted to Drs. M. Dann and W. R. C. Golden for these determinations. had they received vitamin C either as supplements or in their previous diets of heated human or cow's milk (4). The periods of study on the basal diets extended from 2 to 61 days in individual infants, but to conserve space the table is arranged to show only the results obtained on the initial and final days of urinary collections. Following these basal periods, 1-ascorbic acid was administered to 9 of the infants and the results are also shown in Table I.

The initial specimens of urine collected at ages ranging from 6 to 31 days contained total hydroxyphenyl derivatives equivalent to from 223 to $698 \mathrm{mgm}$. of tyrosine per day in all except 3 infants (H. A., F. J. L. and F. L.). The level of excretion in 2 of these infants was insignificant on the first day of observation (aged 19 and 22 days) but after 5 and 8 days, respectively, their excretion rate had attained notable proportions. In the remaining infant (F. L.) the output remained insignificant during a 5-day period of observation (10 to 14 days of age). It is possible that intermediary metabolites might have appeared had the observation been prolonged.

In all 12 infants who excreted hydroxyphenyl compounds, the excretion persisted at high levels for as long as observations were continued on the vitamin C-free diets of cow's milk. In one infant (J. S.) it extended to 78 days of age; on this day he excreted $929 \mathrm{mgm}$. of tyrosine. The range of output in the remaining 11 infants varied from . 291 to $1327 \mathrm{mgm}$. in the final specimens of urine collected on the 12th to the 53rd day of life. The body weight of 6 of the 12 infants at the termination of these basal observations had reached levels well in excess of $2.5 \mathrm{kgm}$., the birth weight customarily used to differentiate full term from premature infants.

The output of $p$-hydroxyphenylpyruvic acid ranged from 36 to $175 \mathrm{mgm}$. per day in the initial specimens of urine in 10 of the infants and reached levels as high as $444 \mathrm{mgm}$. in the final specimens (J. S.). The excretion of keto acids for individual infants comprised from 15 to 34 per cent of the total hydroxyphenyl compounds, the remaining 66 to 85 per cent being almost entirely $p$-hydroxyphenyllactic acid (1).

Effect of vitamin $C$. The parenteral or oral administration to 9 infants of vitamin $\mathrm{C}$ in single 
TABLE I

Spontaneous excretion of hydroxyphenyl derivatives by premature infants fed vitamin $C$-free milk. Effect of vitamin $C$

\begin{tabular}{|c|c|c|c|c|c|c|c|c|c|c|c|c|c|c|c|}
\hline \multirow[b]{2}{*}{$\underset{\text { ject* }}{\text { Sub- }}$} & \multirow[b]{2}{*}{ Age } & \multirow[b]{2}{*}{ Weight } & \multicolumn{2}{|c|}{ Diet } & \multicolumn{2}{|c|}{ Urine } & \multirow[b]{2}{*}{$\begin{array}{c}\text { Plasma } \\
\text { ascor- } \\
\text { bic } \\
\text { acid }\end{array}$} & \multirow[b]{2}{*}{ Sub- $_{\text {ject* }}$} & \multirow[b]{2}{*}{ Age } & \multirow[b]{2}{*}{ Weight } & \multicolumn{2}{|c|}{ Diet } & \multicolumn{2}{|c|}{ Urine } & \multirow[b]{2}{*}{$\begin{array}{l}\text { Plasma } \\
\text { ascor- } \\
\text { bic } \\
\text { acid }\end{array}$} \\
\hline & & & $\begin{array}{c}\text { Nitrogen } \\
\text { intake }\end{array}$ & $\begin{array}{c}\text { b-Ascor- } \\
\text { bic } \\
\text { acidt }\end{array}$ & $\begin{array}{c}\text { Total } \\
\text { hydroxy- } \\
\text { phenyl } \\
\text { com- } \\
\text { pounds } \\
\text { expressed } \\
\text { as } \\
\text { tyrosine }\end{array}$ & $\begin{array}{c}\text { p-Hy- } \\
\text { droxy- } \\
\text { phenyl- } \\
\text { pyruvic } \\
\text { acid }\end{array}$ & & & & & $\begin{array}{c}\text { Nitrogen } \\
\text { intake }\end{array}$ & $\begin{array}{c}\text { l-Ascor- } \\
\text { bic } \\
\text { acidt }\end{array}$ & $\begin{array}{c}\text { Total } \\
\text { hydroxy- } \\
\text { phenyl } \\
\text { com- } \\
\text { pounds } \\
\text { expressed } \\
\text { as } \\
\text { tyrosine }\end{array}$ & $\begin{array}{c}\text { p-Hy- } \\
\text { droxy- } \\
\text { phenyl- } \\
\text { pyruvic } \\
\text { acid }\end{array}$ & \\
\hline \multirow{3}{*}{ P. J. A. } & days & kgm. & $\begin{array}{l}\text { mgm. per } \\
\text { kgm. per } \\
24 \text { hours }\end{array}$ & mgm. & \multicolumn{2}{|c|}{ mgm. per 24 hours } & $\begin{array}{c}\text { mgm. } \\
\text { per } \\
100 \text { cc. }\end{array}$ & \multirow{3}{*}{ J.S. } & \multirow{3}{*}{$\begin{array}{c}\text { days } \\
\\
17 \\
78 \\
79-80 \\
81\end{array}$} & \multirow{2}{*}{$\begin{array}{l}\text { kgm. } \\
2.08 \\
3.96\end{array}$} & \multirow{2}{*}{$\begin{array}{c}\text { mgm. per } \\
\text { kgm. per } \\
24 \text { hours } \\
738 \\
787\end{array}$} & \multirow{3}{*}{$\begin{array}{l}\text { mgm. } \\
100\end{array}$} & \multicolumn{2}{|c|}{ mgm. per 24 hours } & \multirow{3}{*}{$\begin{array}{c}\underset{\text { mgm. }}{\text { per }} \\
100 \mathrm{cc} . \\
0 \\
0\end{array}$} \\
\hline & $\begin{array}{c}6 \\
38 \\
39-41\end{array}$ & $\begin{array}{l}2.00 \\
3.02\end{array}$ & $\begin{array}{l}752 \\
903\end{array}$ & \multirow[t]{2}{*}{500} & $\begin{array}{l}223 \\
953\end{array}$ & $\begin{array}{r}36 \\
145\end{array}$ & & & & & & & $\begin{array}{l}434 \\
929\end{array}$ & $\begin{array}{r}89 \\
444\end{array}$ & \\
\hline & $\begin{array}{l}40 \\
41\end{array}$ & $\begin{array}{l}3.18 \\
3.23\end{array}$ & $\begin{array}{l}857 \\
844\end{array}$ & & $\begin{array}{l}67 \\
33\end{array}$ & $\begin{array}{l}33 \\
15\end{array}$ & & & & 4.00 & 779 & & 68 & 25 & \\
\hline \multirow[t]{2}{*}{ H. C. A. } & $\begin{array}{c}6 \\
46 \\
47-49\end{array}$ & $\begin{array}{l}1.80 \\
3.09\end{array}$ & $\begin{array}{l}809 \\
827\end{array}$ & \multirow{2}{*}{500} & $\begin{array}{r}244 \\
1067\end{array}$ & $\begin{array}{r}39 \\
142\end{array}$ & 0 & J.C. & \multirow{3}{*}{$\begin{array}{c}8 \\
47 \\
48-53 \\
54 \\
54-55 \\
56 \\
56 \\
57\end{array}$} & $\begin{array}{l}3.48 \\
3.76\end{array}$ & $\begin{array}{l}806 \\
837\end{array}$ & \multirow{3}{*}{$\begin{array}{l}95 \\
50 \\
25\end{array}$} & $\begin{array}{l}1327 \\
1258\end{array}$ & $\begin{array}{l}377 \\
160\end{array}$ & 0.3 \\
\hline & $\begin{array}{l}48 \\
49\end{array}$ & $\begin{array}{l}3.20 \\
3.24\end{array}$ & $\begin{array}{l}798 \\
788\end{array}$ & & $\begin{array}{l}38 \\
32\end{array}$ & $\begin{array}{l}6 \\
6\end{array}$ & 0.3 & & & 3.78 & 832 & & 294 & 120 & 0.3 \\
\hline \multirow[t]{2}{*}{ M. P. } & $\begin{array}{l}11 \\
.12\end{array}$ & \begin{tabular}{|l|}
1.98 \\
1.99
\end{tabular} & $\begin{array}{l}898 \\
893\end{array}$ & \multirow[b]{2}{*}{150} & $\begin{array}{l}525 \\
627\end{array}$ & $\begin{array}{l}94 \\
80\end{array}$ & & \multirow[b]{2}{*}{ T. R. } & & 3.88 & 811 & & 38 & 14 & 0.3 \\
\hline & $\begin{array}{c}13-14 \\
15 \\
16\end{array}$ & $\begin{array}{l}2.05 \\
2.10\end{array}$ & $\begin{array}{l}868 \\
845\end{array}$ & & $\begin{array}{l}30 \\
\quad 24\end{array}$ & $\begin{array}{c}3 \\
\text { Trace }\end{array}$ & 0.1 & & \multirow{3}{*}{\begin{tabular}{|l}
21 \\
46 \\
47 \\
47 \\
48 \\
49 \\
50 \\
51 \\
51
\end{tabular}} & $\begin{array}{l}2.16 \\
2.96\end{array}$ & $\begin{array}{l}918 \\
901\end{array}$ & \multirow{2}{*}{50011} & $\begin{array}{r}698 \\
1159\end{array}$ & $\begin{array}{l}175 \\
351\end{array}$ & \\
\hline \multirow[t]{2}{*}{ R. M. G. } & $\begin{array}{c}18 \\
21 \\
22-25\end{array}$ & $\begin{array}{l}1.78 \\
1.88\end{array}$ & $\begin{array}{l}925 \\
875\end{array}$ & 150 & $\begin{array}{l}319 \\
477\end{array}$ & $\begin{array}{r}85 \\
132\end{array}$ & $\mathbf{0}$ & & & $\begin{array}{l}3.00 \\
3.01 \\
3.04 \\
3.03\end{array}$ & $\begin{array}{l}889 \\
886 \\
878 \\
880\end{array}$ & & $\begin{array}{r}907 \\
920 \\
1126 \\
1120\end{array}$ & $\begin{array}{l}152 \\
152 \\
157 \\
143\end{array}$ & 0 \\
\hline & $\begin{array}{c}26 \\
38 \\
38-39 \\
39\end{array}$ & $\begin{array}{l}2.10 \\
2.54 \\
2.62\end{array}$ & $\begin{array}{l}784 \\
814 \\
791\end{array}$ & 400 & $\begin{array}{r}36 \\
714 \\
38\end{array}$ & $\begin{array}{r}5 \\
114 \\
6\end{array}$ & 0.1 & & & $\begin{array}{l}3.04 \\
3.04\end{array}$ & $\begin{array}{l}878 \\
878\end{array}$ & 500 & $\begin{array}{c}9378 \\
1238 \\
47\end{array}$ & $\begin{array}{c}1468 \\
1008 \\
9\end{array}$ & 0.1 \\
\hline R.A.G. & $\begin{array}{l}18 \\
20\end{array}$ & $\begin{array}{l}1.97 \\
2.04\end{array}$ & $\begin{array}{l}876 \\
846\end{array}$ & & $\begin{array}{l}606 \\
534\end{array}$ & $\begin{array}{l}146 \\
136\end{array}$ & $\mathbf{0}$ & W. B. & $\begin{array}{l}19 \\
24 \text { T }\end{array}$ & $\begin{array}{l}1.92 \\
2.00\end{array}$ & $\begin{array}{l}700 \\
672\end{array}$ & & $\begin{array}{l}425 \\
368\end{array}$ & $\begin{array}{l}131 \\
132\end{array}$ & \\
\hline & $\begin{array}{l}22 \\
30 \\
31\end{array}$ & $\begin{array}{l}2.11 \\
2.44\end{array}$ & $\begin{array}{l}818 \\
779\end{array}$ & 200 & $\begin{array}{r}48 \\
612\end{array}$ & $\begin{array}{r}8 \\
185\end{array}$ & o & H.A. & $\begin{array}{l}19 \\
24 \\
29\end{array}$ & $\begin{array}{l}1.49 \\
1.60 \\
1.76\end{array}$ & $\begin{array}{l}642 \\
855 \\
887\end{array}$ & & $\begin{array}{r}54 \\
462 \\
413\end{array}$ & $\begin{array}{r}8 \\
81 \\
87\end{array}$ & \\
\hline & $\begin{array}{l}32 \\
33 \\
34\end{array}$ & $\begin{array}{l}2.52 \\
2.64\end{array}$ & $\begin{array}{l}753 \\
719\end{array}$ & 200 & $\begin{array}{r}340 \\
40\end{array}$ & $\begin{array}{r}120 \\
8\end{array}$ & 0.3 & F. J.L. & $\begin{array}{l}22 \\
30 \\
33\end{array}$ & $\begin{array}{l}1.69 \\
2.00 \\
2.11\end{array}$ & $\begin{array}{l}486 \\
616 \\
584\end{array}$ & & $\begin{array}{r}21 \\
149 \\
291\end{array}$ & $\begin{array}{r}3 \\
32 \\
61\end{array}$ & \\
\hline L. $\mathrm{K}$. & $\begin{array}{l}31 \\
53 \\
54 \\
55\end{array}$ & $\begin{array}{l}1.82 \\
2.70 \\
2.84\end{array}$ & $\begin{array}{l}932 \\
801 \\
880\end{array}$ & $275 \ddagger$ & $\begin{array}{r}437 \\
744 \\
28\end{array}$ & $\begin{array}{c}103 \\
101 \\
\text { Trace }\end{array}$ & 0.1 & F. L. & $\begin{array}{l}10 \\
14\end{array}$ & $\begin{array}{l}2.22 \\
2.49\end{array}$ & $\begin{array}{l}693 \\
742\end{array}$ & & $\begin{array}{l}16 \\
32\end{array}$ & 4 & 0 \\
\hline
\end{tabular}

* Data on the first 5 subjects were presented in a previous communication (3).

$\dagger$ Ascorbic acid was given hypodermically in all infants except T. R. and J. C. in whom it was given orally.

$\$$ Two hundred mgm. Lascorbic acid were given hypodermically; $75 \mathrm{mgm}$. orally.

8 Twelve-hour periods.

II $d$-Isoascorbic acid.

I Vitamin $\mathrm{C}$ given at a later date caused the disappearance of hydroxyphenyl compounds.

or divided doses totaling 100 to $500 \mathrm{mgm}$. 1ascorbic acid resulted without exception in the prompt eradication of abnormal metabolites from the urine. In 2 infants (R. M. G. and R. A. G.) the cycle of appearance of urinary hydroxyphenyl derivatives with omission of vitamin $\mathrm{C}$, and disappearance with its resumption, was demonstrated on two occasions. In another infant (J. C.), the oral administration of $95 \mathrm{mgm}$. of 1 -ascorbic acid in the course of 6 days was without demonstrable effect but continued administration of an additional $75 \mathrm{mgm}$. on the 3 succeeding days resulted in the customary suppression of abnormal urinary metabolites. ${ }^{\circ}$

The oral administration of $500 \mathrm{mgm}$. of isomeric $d$-isoascorbic acid to one infant (T. R.) was accompanied by a transient decrease of approximately 20 per cent in the excretion of hy-

6 The prophylactic action of vitamin $C$ was also demonstrated in a group of 11 premature infants whose basal diets of heated cow's milk had been supplemented by a total of at least $70 \mathrm{mgm}$. 1-ascorbic acid prior to observations. In 7 , the spontaneous excretion of hydroxyphenyl compounds was entirely prevented by the prior administration of 70 to $100 \mathrm{mgm}$. 
TABLE II

Excretion of hydroxyphenyl derivatives by full term infants fed vitamin C-free cow's milk

\begin{tabular}{|c|c|c|c|c|c|c|c|}
\hline \multirow[b]{2}{*}{ Subject } & \multirow[b]{2}{*}{ Age } & \multirow[b]{2}{*}{ Weight } & \multirow[b]{2}{*}{$\begin{array}{l}\text { Nitrogen } \\
\text { intake }\end{array}$} & \multicolumn{2}{|c|}{ Urine } & \multirow[b]{2}{*}{$\begin{array}{c}\text { Plasma } \\
\text { ascorbic } \\
\text { acid }\end{array}$} & \multirow[b]{2}{*}{ Remarks } \\
\hline & & & & $\begin{array}{c}\text { Total } \\
\text { hydroxy- } \\
\text { phenyl } \\
\text { com- } \\
\text { pounds } \\
\text { expressed } \\
\text { as } \\
\text { tyrosine }\end{array}$ & $\begin{array}{l}\text { p-Hydroxy- } \\
\text { phenyl- } \\
\text { pyruvic } \\
\text { acid }\end{array}$ & & \\
\hline $\begin{array}{l}\text { W. Br. } \\
\text { M. S. } \\
\text { B. B. } \\
\text { B. L. } \\
\text { G. T. } \\
\text { R. J. } \\
\text { J. R. } \\
\text { P. K. } \\
\text { B. C. } \\
\text { V. P. } \\
\text { V. D. } \\
\text { J. O. }\end{array}$ & $\begin{array}{r}\text { days } \\
9 \\
9 \\
13 \\
16 \\
21 \\
27 \\
30 \\
36 \\
42 \\
58 \\
143 \\
195 \\
36 \\
51 \\
\\
53\end{array}$ & $\begin{array}{l}\text { kgm. } \\
3.59 \\
4.94 \\
3.70 \\
3.16 \\
4.30 \\
2.78 \\
3.71 \\
3.86 \\
4.30 \\
6.88 \\
5.38 \\
3.42 \\
3.90 \\
500 \\
4.00\end{array}$ & $\begin{array}{c}\text { mgm. per } \\
\text { kgm. per } \\
24 \text { hours } \\
819 \\
865 \\
869 \\
812 \\
851 \\
1066 \\
876 \\
868 \\
955 \\
820 \\
826 \\
900 \\
903 \\
\text { gm. l-asc } \\
881\end{array}$ & $\begin{array}{c}\text { mgm. pe } \\
15 \\
39 \\
12 \\
72 \\
17 \\
24 \\
24 \\
14 \\
19 \\
24 \\
48 \\
1171 \\
1450 \\
\text { rbic acid } \\
45\end{array}$ & \begin{tabular}{|}
24 hours \\
Trace \\
19 \\
13 \\
20 \\
6 \\
Trace \\
7 \\
4 \\
2 \\
5 \\
9 \\
350 \\
449 \\
orally \\
7
\end{tabular} & $\begin{array}{c}\text { mgm. } \\
\text { per } \\
100 \text { cc. } \\
0.1 \\
0.1\end{array}$ & $\begin{array}{l}\text { Hemorrhagic disease of the newborn. } \\
\text { Hemorrhagic disease of the newborn. } \\
\text { Hemorrhagic disease of the newborn. } \\
\text { Birth injury. } \\
\text { Cleft palate. } \\
\text { Feeding problem.* } \\
\text { Staphylococcus sepsis; bronchopneumonia. } \\
\text { Pyloric stenosis, postoperative. } \\
\text { Conjunctivitis. } \\
\text { Bronchopneumonia. } \\
\text { Malnutrition; respiratory infection. } \\
\text { Feeding problem; convulsions. }\end{array}$ \\
\hline
\end{tabular}

* On this day the infant received $l$-ascorbic acid (20 mgm.) for the first time.

droxyphenyl compounds, with a return to the foreperiod level on the 3rd day following treatment (over $1100 \mathrm{mgm}$. in 24 hours). Five days later, an equal oral dose of 1 -ascorbic acid abolished the excretion of these substances within 48 hours. The minimal effect of $d$-isoascorbic acid on the metabolism of aromatic amino acids (9) is commensurate with its recognized lesser antiscorbutic potency (10).

Ascorbic acid was not detectable in the blood plasma of 6 infants in the vitamin C-deficient periods, and in 5, correction of the metabolic error by the vitamin was not accompanied by appreciable elevations of the plasma levels which remained at 0 to $0.1 \mathrm{mgm}$. per $100 \mathrm{cc}$. even after $100 \mathrm{mgm}$. or more of 1 -ascorbic acid had been given. The rise in the ascorbic acid content of the plasma of 3 other infants following administration of the vitamin did not exceed $0.3 \mathrm{mgm}$. per $100 \mathrm{cc}$. The complete absence or slight elevation of the ascorbic acid content of the blood plasma in the face of repair of the defect in cellular metabolism is in accord with published data (11) stating that replenishment of intracellular stores precedes and is not necessarily reflected in the plasma levels.
Roentgenograms of the long bones of 10 infants were, as might have been expected from their ages (12), essentially negative. It is well known, however, that a prolonged period may intervene between histological manifestations of scurvy and perceptible roentgenographic changes (13).

Absence of spontaneous excretion of hydroxyphenyl compounds by full term infants. In Table II are presented the results obtained in a group of 12 full term infants ranging from 9 to 195 days of age who were fed cow's milk mixtures devoid of vitamin $\mathrm{C}$, and with a protein intake ( 5.1 to 6.6 grams per $\mathrm{kgm}$. per day) comparable to that of the premature infants. None of these infants had previously received vitamin $\mathrm{C}$ in their diets or as supplements, with one exception (V. P.) who had been breast-fed until his admission to the hospital for bronchopneumonia 3 weeks prior to observation. In contrast to the results obtained in premature infants, 11 of the 12 subjects excreted insignificant amounts of hydroxyphenyl derivatives. ${ }^{7}$

7 The single infant (J. O.) who excreted large amounts of aromatic metabolites was classified as a full term infant because his birth weight of 2530 grams exceeded 
The ability of full term infants and the failure of premature infants to metabolize aromatic amino acids completely under similar conditions of diet cannot be fully explained at present, but two possibilities may be mentioned. One presupposes a more complete development with full fetal maturation of the enzyme systems involved in the breakdown of these amino acids analogous to the differential rate of fetal development of the chain of enzymes concerned with the metabolism of purines (14) and other substances. The persistent failure of hydroxyphenyl compounds to appear in significant amounts in the urine of one full term infant of $61 / 2$ months (V. D.) who, according to his history, had been on a vitamin Cdeficient diet from birth and who presumably was in an extreme state of vitamin $\mathrm{C}$ desaturation (11b), and the prompt eradication of these substances from the urine of another full term infant (G. T., Table V) by the administration of a vitamin $\mathrm{C}$-free liver extract, suggest that full fetal maturity may bring with it a factor or factors, not solely dependent on vitamin $C$, capable of completing the degradation of aromatic amino acids. The failure of vitamin $C$ to suppress the urinary excretion of the aromatic amino acid metabolites, homogentisic acid and phenylpyruvic acid in the inborn anomalies, alkaptonuria (15) and phenylpyruvic oligophrenia (16), has already been established.

The second, and perhaps more likely possibility, presupposes quantitative differences in the body stores of vitamin $C$ in premature and full term infants. This concept is supported both by analogy to the known differences in body storage of calcium and other substances in fetuses of different ages (17) and by direct evidence. Tissue analyses (18) have shown that the ascorbic acid content of the livers of premature infants at or shortly after birth is lower than that of full term infants under similar conditions of maternal diet. Tolerance tests indicate that young premature infants excrete only 10 to 15 per cent of a test dose

the standard of 2500 grams ( $51 / 2 \mathrm{lbs}$.) statistically used to divide premature from full term infants. His history stated, however, that "he was born 2 to 3 weeks before term and required incubator care." The oral administration of $500 \mathrm{mgm}$. 1-ascorbic acid to this infant on the 52nd day of life promptly abolished the urinary excretion of intermediary metabolites (Table II). of vitamin C in 24 hours (19) in contrast to 28 per cent excreted by full term infants following an equivalent dosage (20). The absence of hydroxyphenyl derivatives in the initial urine specimens of some premature infants (Table I), and their subsequent appearance with no change in diet, may be explained on the basis of progressive depletion of the vitamin $C$ stores of the body. Furthermore, the excretion of these metabolites persisted in all of the premature infants for as long as they were observed; in one infant up to 78 days of age and $4.0 \mathrm{kgm}$. in weight. If one makes the reasonable assumption that, at this late age the enzyme systems of this premature infant had attained a stage of development commensurate with that of an infant born at term, the persistence of the defect indicates the fundamental position of vitamin $\mathrm{C}$ in completing the oxidation of aromatic amino acids in these infants.

Effect of ingestion of tyrosine and phenylalanine by full term infants. Since the ingestion of single doses of phenylalanine and tyrosine always increased the excretion of hydroxyphenyl compounds in premature infants on vitamin C-free diets of cow's milk (1), the effect of these amino acids was determined in 2 of the full term infants previously studied (Table II) under similar dietary conditions.

Both infants responded to ingestion of the amino acids (1.0 gram per $\mathrm{kgm}$.) by a prompt and persistent rise in excretion of hydroxyphenyl compounds. Maximum levels of 1050 and 1750 mgm. were attained on the 7 th and 12 th days following ingestion, the maximal levels for $p$ hydroxyphenylpyruvic acid being 460 and 528 mgm. on the 4th and 6 th days, respectively. In infant J. R., these substances were still present in large amounts (1343 and $353 \mathrm{mgm}$.) 18 days after the feeding. The ingestion by these 2 infants of a single dose of 1.0 gram of tyrosine or phenylalanine per $\mathrm{kgm}$. was apparently sufficient to disrupt the enzymatic mechanisms responsible for complete oxidation of aromatic amino acids and to initiate a persistent change in their cellular metabolism, whereas the daily ingestion of slowly absorbed, divided doses of one-half this amount ( 0.5 gram per $\mathrm{kgm}$. as components of the protein of the basal diet of cow's milk (1)) did not flood the cells to the point of precipitating the defect in 
TABLE III

Effect of ingestion of tyrosine and phenylalanine on excretion of hydroxyphenyl derivatives in full term infants

\begin{tabular}{|c|c|c|c|c|c|}
\hline \multirow[b]{2}{*}{ Subject } & \multirow[b]{2}{*}{ Age } & \multirow[b]{2}{*}{ Weight } & \multirow[b]{2}{*}{$\begin{array}{c}\text { Nitrogen } \\
\text { intake }\end{array}$} & \multicolumn{2}{|c|}{ Urine } \\
\hline & & & & $\begin{array}{c}\text { Total } \\
\text { hydroxy- } \\
\text { phenyl } \\
\text { compounds } \\
\text { expressed as } \\
\text { tyrosine }\end{array}$ & $\begin{array}{c}\text { p-Hydroxy- } \\
\text { phenyl- } \\
\text { pyruvic } \\
\text { acid }\end{array}$ \\
\hline \multirow{3}{*}{ G. T. } & days & kgm. & $\begin{array}{l}\text { mgm. per } \\
\text { kgm. per }\end{array}$ & \multicolumn{2}{|c|}{ mgm. per 24 hours } \\
\hline & $\begin{array}{l}27 \\
28\end{array}$ & $\begin{array}{l}4.30 \\
4.42 \\
4.3\end{array}$ & $\begin{array}{l}851 \\
828\end{array}$ & $\begin{array}{l}17 \\
18\end{array}$ & $\begin{array}{l}6 \\
7\end{array}$ \\
\hline & $\begin{array}{l}29 \\
30 \\
31 \\
32 \\
35\end{array}$ & $\begin{array}{l}4.40 \\
4.48 \\
4.50 \\
4.54 \\
4.60\end{array}$ & $\begin{array}{l}907 \\
817 \\
806 \\
806 \\
796\end{array}$ & $\begin{array}{r}309 \\
742 \\
932 \\
1022 \\
1050\end{array}$ & $\begin{array}{l}198 \\
407 \\
432 \\
460 \\
290\end{array}$ \\
\hline \multirow[t]{3}{*}{ J. R. } & $\begin{array}{l}36 \\
39\end{array}$ & $\begin{array}{l}3.71 \\
3.70\end{array}$ & $\begin{array}{l}876 \\
878\end{array}$ & $\begin{array}{r}24 \\
22\end{array}$ & $\begin{array}{l}7 \\
9\end{array}$ \\
\hline & $\begin{array}{l}40 \\
41 \\
42 \\
45 \\
51 \\
57\end{array}$ & $\begin{array}{l}\text { grams } \\
3.76 \\
3.82 \\
3.80 \\
4.02 \\
4.10 \\
4.21\end{array}$ & $\begin{array}{l}\text { phenyl } \\
940 \\
851 \\
855 \\
926 \\
918 \\
894\end{array}$ & $\begin{array}{r}\text { lanine } \\
762 \\
1636 \\
1512 \\
1741 \\
1750 \\
1343\end{array}$ & $\begin{array}{l}406 \\
593 \\
472 \\
528 \\
419 \\
353\end{array}$ \\
\hline & $\begin{array}{l}60 \\
61\end{array}$ & $\begin{array}{l}\text { 1gm. } \\
4.30 \\
4.30\end{array}$ & $\begin{array}{l}875 \\
875\end{array}$ & $\begin{array}{r}\text { orally } \\
361 \\
16\end{array}$ & $\begin{array}{r}68 \\
3\end{array}$ \\
\hline
\end{tabular}

these subjects. As previously mentioned (Table I), the latter dosage as components of cow's milk protein consistently provoked the defect in premature infants.

The oral administration of $500 \mathrm{mgm}$. of 1 ascorbic acid to one of the full term infants ( $\mathrm{J}$. R.) was as effective in eradicating the artificially produced defect as in abolishing the spontaneous excretion by premature infants. In addition to this therapeutic effect, the prophylactic action of vitamin $\mathrm{C}$ on the artificially induced defect was demonstrated in 4 other full term infants. The prior inclusion of from 70 to $450 \mathrm{mgm}$. 1-ascorbic acid in their basal diet prevented the rise in excretion of abnormal metabolites following ingestion of phenylalanine or tyrosine in dosages of from 0.5 to 1.0 gram per $\mathrm{kgm}$. in 5 of 6 observations. In the one infant in whom $70 \mathrm{mgm}$. ascorbic acid failed to prevent the rise in excretion resulting from the ingestion of the aromatic amino acid, the administration of an additional $80 \mathrm{mgm}$. proved an effective preventive in a second feeding observation with the amino acid.
Specificity of vitamin $C$. In order to establish the specific rôle of vitamin $\mathrm{C}$ in completing the oxidation of aromatic amino acids, a large number of other substances were administered to a number of premature infants receiving vitamin C-free diets of cow's milk. Such studies seemed particularly indicated since Closs and Fölling (21) had demonstrated an increased excretion of phenylpyruvic acid in thiamine-deficient rats following injection of phenylalanine.

No diminution in the urinary excretion of hydroxyphenyl derivatives followed administration of the substances as listed: thiamine chloride, 20 mgm. hypodermically on each of 4 days to 2 infants, and $10 \mathrm{mgm}$. daily by mouth for 3 days to one infant; riboflavin, $1 \mathrm{mgm}$. hypodermically for 3 days to one infant; nicotinic acid, 60, 40 and $20 \mathrm{mgm}$. hypodermically on each of 3 days to one infant; pyridoxine (vitamin $\mathrm{B}_{\mathrm{s}}$ ), $20 \mathrm{mgm}$. by mouth daily for 3 days followed by $10 \mathrm{mgm}$. daily in combination with $2 \mathrm{cc}$. of vitamin $\mathrm{H}$ parenterally for 4 more days to one infant; adrenal cortex (cortate), $5 \mathrm{mgm}$. daily for 3 days to one infant, and $a$-tocopherol, 25, 50, and $25 \mathrm{mgm}$. hypodermically on each of 3 days to one infant. One infant was fed vitamin B-complex in the form of rice polishings, a yeast preparation and a crude liver extract in 3 successive periods of 4 days each without effect. ${ }^{8}$

In Table IV the lack of effect in one infant of various fractions of the vitamin $B$ complex when given serially is demonstrated. This infant was studied throughout a prolonged period of 66 days (from 17 to 83 days of age), for the first 61 days of which he received the customary diet of vitamin C-free cow's milk supplemented with adequate amounts of vitamins $A$ and $D$.

Thiamine chloride, riboflavin, nicotinic acid, pyridoxine $\left(\mathrm{B}_{6}\right)$, choline chloride, vitamin $\mathrm{H}$ and pantothenic acid administered in large amounts in summation from the 19th to the 58th day of age produced no consistent change in excretion of aromatic metabolites, their output showing a progressively higher trend with increasing age.

8 The daily dosage of these preparations -8 grams of ryzamin (Burroughs-Wellcome), 3 grams of powdered yeast. (International Vitamin Corporation) and $6 \mathrm{cc}$. of liver extract (Lederle B-complex)-each supplied approximately $2 \mathrm{mgm}$. of thiamine chloride as well as varying amounts of other fractions of the B complex. 
The subsequent feeding, between the 63rd and 74th day, of a concentrated crude liver extract (a total of $8 \mathrm{cc}$. in 5 days) and the injection of such an extract fortified with thiamine and riboflavin ( 7 cc. in 4 days) also yielded equivocal results. Daily fluctuations in excretion notably exceeded those observed in other infants but they could not be definitely related to the administration of the various supplements. ${ }^{9}$ The injection

9 Attention is called to the somewhat lower rate of excretion between the 49th and 58th days (following the addition of pantothenic acid-Merck-to the other components of the $B$ complex) and also between the 64th and 67th days (during the administration of crude liver extract-Lederle B-complex) and to the higher excretion rate on the last (62nd) day of the intervening 4-day control period of basal diet without extra supplements. The significance of these variations is not clear because of the large day-to-day fluctuations. of relatively small amounts of 1 -ascorbic acid ( 50 $\mathrm{mgm}$. on the 79th day and $25 \mathrm{mgm}$. on the 80th and 81st day) caused the customary but unexpectedly prompt decrease in the excretion of hydroxyphenyl derivatives in view of the degree of vitamin $C$ deficiency which must have been present in an infant of this age who had never received the vitamin.

Effect of liver extract. In addition to the aforementioned observations with the different components of the vitamin B-complex given singly and in combination, the effect of parenteral administration of a concentrated crude liver extract fortified with thiamine and riboflavin ${ }^{10}$ was studied in one full term and 3 additional premature infants.

10 Liver extract E-795 (Eli Lilly and Co.).

TABLE IV

Effect of administration of vitamin $B$ on the excretion of hydroxyphenyl derivatives*

\begin{tabular}{|c|c|c|c|c|c|c|c|c|c|c|c|}
\hline \multirow[b]{2}{*}{ Age } & \multicolumn{9}{|c|}{ Medication† } & \multirow[b]{2}{*}{$\begin{array}{c}\text { Total } \\
\text { hydroxyphenyl } \\
\text { compounds } \\
\text { expressed as } \\
\text { tyrosine }\end{array}$} & \multirow[b]{2}{*}{$\begin{array}{l}\text { p-Hydroxy- } \\
\text { phenyl- } \\
\text { pyruvic } \\
\text { acid }\end{array}$} \\
\hline & $\begin{array}{l}\text { Thia- } \\
\text { mine }\end{array}$ & $\begin{array}{l}\text { Ribo- } \\
\text { flavin }\end{array}$ & $\begin{array}{l}\text { Nico- } \\
\text { tinic } \\
\text { acid }\end{array}$ & B。 & $\underset{\mathrm{Cl}}{\text { Choline }}$ & $\mathbf{H}$ & $\begin{array}{l}\text { Panto- } \\
\text { thenic } \\
\text { acid }\end{array}$ & $\begin{array}{l}\text { Crude } \\
\text { liver } \\
\text { extract }\end{array}$ & $\begin{array}{l}\text { Crude } \\
\text { liver } \\
\text { extract } \\
\text { plus } \\
\text { thiamine } \\
\text { and } \\
\text { riboflavin }\end{array}$ & & \\
\hline $\begin{array}{l}\text { days } \\
17 \\
18 \\
19 \\
20 \\
21 \\
22 \\
23 \\
24 \\
25 \\
26 \\
27 \\
28 \\
29 \\
30 \\
31 \\
32 \\
33 \\
34 \\
35 \\
36 \\
37 \\
38 \\
39 \\
40 \\
41 \\
42\end{array}$ & $\begin{array}{r}\text { mgm. } \\
\\
7.5 \\
\mathbf{1 7 . 5} \\
\mathbf{5 . 0} \\
\mathbf{5 . 0} \\
\mathbf{5 . 0} \\
\mathbf{5 . 0} \\
\mathbf{5 . 0} \\
\mathbf{5 . 0} \\
\mathbf{5 . 0} \\
\mathbf{5 . 0} \\
\mathbf{5 . 0} \\
\mathbf{5 . 0} \\
\mathbf{5 . 0} \\
\mathbf{5 . 0} \\
\mathbf{5 . 0} \\
\mathbf{5 . 0} \\
\mathbf{5 . 0} \\
\mathbf{5 . 0} \\
\mathbf{5 . 0} \\
\mathbf{5 . 0} \\
\mathbf{5 . 0} \\
\mathbf{5 . 0} \\
\mathbf{5 . 0} \\
\mathbf{5 . 0}\end{array}$ & $\begin{array}{l}2.0 \\
2.0 \\
2.0 \\
2.0 \\
2.0 \\
2.0 \\
2.0 \\
2.0 \\
2.0 \\
2.0 \\
2.0 \\
2.0 \\
2.0 \\
2.0 \\
2.0 \\
2.0 \\
2.0 \\
2.0 \\
2.0 \\
2.0\end{array}$ & $\begin{array}{l}10 \\
10 \\
10 \\
10 \\
10 \\
10 \\
10 \\
10 \\
10 \\
10 \\
10 \\
10 \\
10 \\
10 \\
10 \\
10 \\
10\end{array}$ & $\begin{array}{l}10 \\
10 \\
10 \\
10 \\
10 \\
10 \\
10 \\
10 \\
10 \\
10 \\
10 \\
10 \\
10\end{array}$ & $\begin{array}{l}0.5 \\
0.5 \\
0.5 \\
0.5 \\
0.5 \\
0.5 \\
0.5 \\
0.5 \\
0.5\end{array}$ & 2.0 & mgm. & $c c$. & $c c$. & $\begin{array}{c}\text { mgm. per } \\
24 \text { hours } \\
434 \\
393 \\
462 \\
\\
572 \\
657 \\
\\
586 \\
625 \\
\\
679 \\
695 \\
\\
798 \\
786 \\
\\
818 \\
840 \\
\\
975 \\
901 \\
741\end{array}$ & $\begin{array}{c}\text { mgm. per } \\
24 \text { hours } \\
89 \\
86 \\
99 \\
\\
122 \\
147 \\
115 \\
123 \\
\\
127 \\
135 \\
\\
153 \\
163 \\
\\
155 \\
166 \\
187 \\
163 \\
126\end{array}$ \\
\hline
\end{tabular}

* Infant J. S. Weight $2.06 \mathrm{kgm}$. at onset of observations and $4.00 \mathrm{kgm}$. at end. The basal diet consisted of a cow's milk mixture containing an average nitrogen intake of $739 \mathrm{mgm}$. per $\mathrm{kgm}$. per day with added supplements of vitamins $A$ (28,000 international units) and.D (4000 international units).

$\dagger$ All substances were given by mouth except factor $H$, pantothenic acid and crude liver extract fortified with thiamine and riboflavin which were administered hypodermically. 
TABLE IV-Continued

\begin{tabular}{|c|c|c|c|c|c|c|c|c|c|c|c|}
\hline \multirow[b]{2}{*}{ Age } & \multicolumn{9}{|c|}{ Medication $\uparrow$} & \multirow[b]{2}{*}{$\begin{array}{c}\text { Total } \\
\text { hydroxyphenyl } \\
\text { compounds } \\
\text { expressed as } \\
\text { tyrosine }\end{array}$} & \multirow[b]{2}{*}{$\begin{array}{c}\text { p-Hydroxy- } \\
\text { phenyl- } \\
\text { pyruvic } \\
\text { acid }\end{array}$} \\
\hline & $\begin{array}{l}\text { Thia- } \\
\text { mine }\end{array}$ & $\begin{array}{l}\text { Ribo- } \\
\text { flavin }\end{array}$ & $\begin{array}{l}\text { Nico- } \\
\text { tinic } \\
\text { acid }\end{array}$ & $B_{6}$ & $\underset{\mathrm{Cl}}{\text { Choline }}$ & H & $\begin{array}{l}\text { Panto- } \\
\text { thenic } \\
\text { acid }\end{array}$ & $\begin{array}{l}\text { Crude } \\
\text { liver } \\
\text { extract }\end{array}$ & $\begin{array}{c}\text { Crude } \\
\text { liver } \\
\text { extract } \\
\text { plus } \\
\text { thiamine } \\
\text { and } \\
\text { riboflavin }\end{array}$ & & \\
\hline $\begin{array}{c}\text { days } \\
43 \\
44 \\
47 \\
48 \\
49 \\
50 \\
51 \\
52 \\
53 \\
54 \\
55 \\
56 \\
57 \\
58 \\
62 \\
63 \\
64 \\
65 \\
66 \\
67 \\
68 \\
69 \\
70 \\
71 \\
72 \\
73 \\
74 \\
75 \\
76 \\
77 \\
78\end{array}$ & $\begin{array}{l}5.0 \\
5.0 \\
5.0 \\
5.0\end{array}$ & $\begin{array}{l}2.0 \\
2.0 \\
2.0 \\
2.0\end{array}$ & $\begin{array}{c}m g m . \\
10\end{array}$ & $\begin{array}{l}10 \\
10 \\
10 \\
10\end{array}$ & $\begin{array}{c}\underset{m g m . p e r}{m g m . p e r} \\
\text { kgm. } \\
0.5\end{array}$ & $\begin{array}{l}4.0 \\
4.0\end{array}$ & $\begin{array}{l} \\
10 \\
10 \\
10 \\
10 \\
10 \\
10 \\
10 \\
10 \\
10 \\
10\end{array}$ & $\begin{array}{l}2 \\
2 \\
2 \\
1 \\
1\end{array}$ & $\begin{array}{l}2 \\
2 \\
2 \\
1\end{array}$ & 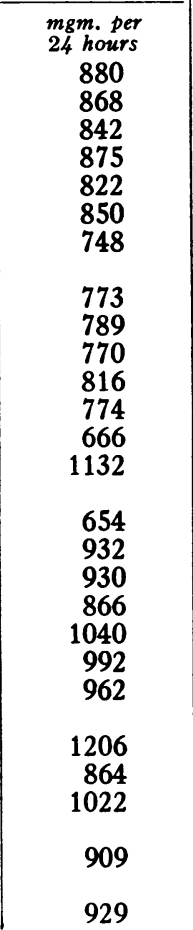 & 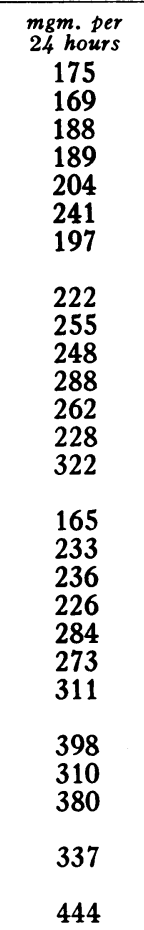 \\
\hline $\begin{array}{l}81 \\
83\end{array}$ & & & & & & -1 & . & $\mathrm{p}$ & & $\begin{array}{l}68 \\
51\end{array}$ & $\begin{array}{l}25 \\
23\end{array}$ \\
\hline
\end{tabular}

In 2 of the premature infants, J. S. (Table IV) and L. K., treatment with 7 and $8 \mathrm{cc}$. of the liver extract ( 1 or $2 \mathrm{cc}$. daily) was entirely without effect on the excretion of aromatic metabolites ; in another infant (W. B.) treatment with the same extract ( 2 cc. daily for 3 days) produced a moderate decrease in the daily output of these substances from 368 to 270 mgm., a decline of approximately 26 per cent. ${ }^{11}$ The fourth premature

11 On the day following the last injection of liver this infant received 1 gram $d$-isoascorbic acid orally. The abnormal metabolites completely disappeared from his urine and their excretion remained negligible for as long as 13 days thereafter when the observation was discontinued. Further studies on additional premature infants are being undertaken to determine whether these two agents are capable of exerting a synergistic effect infant ( $T$. R.) responded to the parenteral administration of the extract ( 2 cc. daily for 3 days) with a transient but definite drop of approximately 40 per cent from the daily foreperiod level of $764 \mathrm{mgm}$. to $456 \mathrm{mgm}$.

In contrast to the absent or moderate and transient responses of premature infants to injections of liver extract, one full term infant (G. T.), in whom the defect had been provoked by tyrosine ingestion, responded to comparable treatment (a total of $6 \mathrm{cc}$. in 4 days) with a prompt and persistent eradication of excretion of hydroxyphenyl compounds. Further observations

on the metabolic defect in these subjects, since the action of 0.5 gram $d$-isoascorbic acid alone (Table I) was only transient and slight. 
TABLE $v$

Effect of the administration of liver extract on the excretion of hydroxyphenyl derivatives

\begin{tabular}{|c|c|c|c|c|c|c|c|c|c|}
\hline \multirow{3}{*}{ 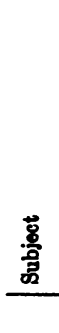 } & \multirow{3}{*}{$\frac{8}{d a y s}$} & \multirow{3}{*}{ 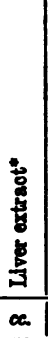 } & \multicolumn{2}{|c|}{ Urine } & \multirow[b]{2}{*}{$\begin{array}{l}\text { 葛 } \\
\text { 昜 }\end{array}$} & \multirow[b]{2}{*}{8} & \multirow[b]{2}{*}{ 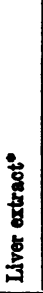 } & \multicolumn{2}{|c|}{ Urine } \\
\hline & & & 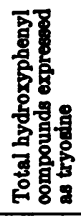 & 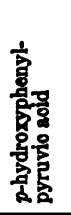 & & & & 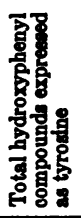 & 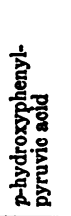 \\
\hline & & & \multicolumn{2}{|c|}{ mom. per 24 hours } & & doys & $\infty$. & \multicolumn{2}{|c|}{ mom. per 24 hours } \\
\hline \multicolumn{5}{|c|}{ PREATTORE INTANTS } & \multicolumn{5}{|c|}{ PREMATORE ITFANT } \\
\hline L. $\mathbf{K}$. & \multirow{3}{*}{$\begin{array}{l}46 \\
47 \\
48 \\
49 \\
50 \\
51 \\
52 \\
53 \\
22 \\
23 \\
24 \\
25 \\
26 \\
27 \\
28\end{array}$} & \multirow[t]{3}{*}{$\begin{array}{l}2 \\
2 \\
1 \\
2 \\
1\end{array}$} & \multirow{2}{*}{$\begin{array}{l}866 \\
869 \\
\\
765 \\
837 \\
744 \\
896 \\
409 \\
368\end{array}$} & \multirow{2}{*}{$\begin{array}{l}166 \\
203 \\
\\
154 \\
159 \\
101 \\
131 \\
129 \\
132\end{array}$} & T. R. & $\begin{array}{l}32 \\
33 \\
34 \\
35 \\
36 \\
37 \\
38 \\
39\end{array}$ & $\begin{array}{l}\mathbf{2} \\
\mathbf{2} \\
\mathbf{2}\end{array}$ & $\begin{array}{l}764 \\
762 \\
694 \\
578 \\
456 \\
456 \\
473 \\
614\end{array}$ & $\begin{array}{l}246 \\
264 \\
207 \\
157 \\
127 \\
146 \\
162 \\
200\end{array}$ \\
\hline W. B. & & & & & \multicolumn{5}{|c|}{ FULI TERY ITIANT } \\
\hline & & & $\begin{array}{l}367 \\
270\end{array}$ & $\begin{array}{r}120 \\
77\end{array}$ & G. T.t & $\begin{array}{l}35 \\
36 \\
37 \\
38 \\
39 \\
40 \\
41 \\
48\end{array}$ & $\begin{array}{l}2 \\
2 \\
1 \\
1\end{array}$ & $\begin{array}{r}1050 \\
974 \\
646 \\
356 \\
50 \\
26 \\
25 \\
41\end{array}$ & $\begin{array}{r}290 \\
260 \\
173 \\
90 \\
9 \\
5 \\
5 \\
12\end{array}$ \\
\hline
\end{tabular}

* Crude liver extract fortified with thiamine and riboflavin, given intramuscularly.

$\uparrow$ Metabolic defect produced by ingestion of tyrosine on 29th day of life.

are at present being made on other full term infants. If the potency of liver extract ${ }^{12}$ in the latter is substantiated, it will illustrate another point of difference between premature and full term infants.

\section{COMMENT}

An aberration in the metabolism of aromatic amino acids has been demonstrated in premature infants who are fed relatively high protein diets ( 5 grams or more per $\mathrm{kgm}$. per day) in the form of cow's milk without supplements of vitamin C. This aberration is, as a rule, not spontaneously demonstrable in full term infants on similar diets but it may be artificially provoked in them by

12 The liver extract which was used in these observations was tested and found to contain no vitamin C. Although reducing substances were present, the rate of color development differed from that of the vitamin. Furthermore, the manufacturer reported that the method of processing the liver extract undoubtedly destroyed any vitamin $\mathbf{C}$ originally present. the feeding of $d, 1$-phenylalanine or 1-tyrosine. It consists in the inability of these subjects to oxidize these aromatic amino acids beyond the organic acid stage and is manifested by the appearance in their urine of the intermediary products, $p$-hydroxyphenylpyruvic and 1-p-hydroxyphenyllactic acids. The absence of other intermediary metabolites (except phenylpyruvic acid following the ingestion of phenylalanine) has been established by appropriate tests. This metabolic defect may be prevented or, when present, may be promptly abolished by the administration of vitamin $C$ in adequate dosage. Its reversibility differentiates it from the hereditary anomalies, alkaptonuria and phenylpyruvic oligophrenia, both of which have been shown not to be remediable by the administration of vitamin $C(17,18)$. The spontaneous occurrence of the defect in the premature infant provides a good medium for the study of the intermediary metabolism of aromatic amino acids in the growing human organism.

The reported data indicate that the metabolic error observed in infants is dependent on at least three factors: (1) the level of protein (aromatic amino acid) intake, (2) the degree of vitamin C saturation of the tissues, and (3) the maturity of the infant. The last factor may be solely a function of the second or it may be related in part to a more complete development in the full term infant of the enzyme systems involved in aromatic amino acid metabolism. The evidence favoring these alternate concepts has already been considered.

The reported observations do establish beyond any doubt the key position of vitamin $C$ in the metabolism of aromatic amino acids in the growing human organism. If the metabolism of these amino acids increases the vitamin $\mathrm{C}$ requirement (9), their higher content in cow's milk may contribute to the observed lower plasma levels of vitamin $C$ in infants on this feeding than in those fed human milk (22) and to the increased incidence of scurvy in infants fed cow's milk. This possibility is at present being investigated. If substantiated, it will supplement the explanation usually offered for the above differences in the plasma ascorbic acid of infants fed human and cow's milk, namely, the difference in content of vitamin $\mathrm{C}$ of the two diets. 
Demonstration of the fundamental importance of vitamin $\mathrm{C}$ in aromatic amino acid metabolism suggests the possibility of employing the exhibition of the metabolic defect, either spontaneous or induced, for the early detection of vitamin C deficiency in premature and young infants. Although the defect appeared in several infants as early as the first week of life, the fact that a relatively high intake of aromatic amino acids was required for exhibition of the defect sharply limits its usefulness as a test for vitamin $\mathrm{C}$ deficiency. The evidence does indicate, on the other hand, that exhibition of the defect represents an extreme degree of vitamin $\mathrm{C}$ desaturation of the tissues and that disappearance of abnormal urinary metabolites, when previously present, may constitute an early and sensitive sign of repair of intracellular vitamin $\mathrm{C}$ deficiency. The prompt correction of the metabolic error following vitamin $C$ administration, in the absence of any appreciable rise in the ascorbic acid level of the plasma, indicates that the former effect is a much more delicate indicator of such repair than changes in blood plasma ascorbic acid levels.

The observations reported in this paper give rise to a number of intriguing but as yet highly conjectural questions. What is the relation, if any, between the demonstrated defect in the metabolism of tyrosine and phenylalanine and the morphologic changes characteristic of vitamin C deficiency, namely, improper formation of intercellular substance and collagen (23) ? Since tyrosine is a precursor of both thyroxine and adrenalin, may the presence of the defect in premature infants contribute, under certain conditions, to their instability of body temperature regulation? Is the delicate transparency of the skin of premature infants related to improper utilization of melanin, another product of tyrosine? Does the observed increased excretion of aromatic organic acids in premature infants fed cow's milk play a rôle in their known tendency to develop severe rickets? If so, this observation may explain, in part at least, the frequently postulated importance of vitamin C in the development of rickets. Many more questions arise but they are all matters of surmise at present and they must await further study before meriting consideration.

\section{SUMMARY}

Premature infants. Premature infants fed diets of vitamin C-free cow's milk containing 5 grams or more of protein per kgm. exhibited a spontaneous defect in metabolism of aromatic amino acids manifested by the excretion in their urine of 1-p-hydroxyphenyllactic and $p$-hydroxyphenylpyruvic acids. This defect was noted as early as the 6th day of life and persisted for as long as vitamin $\mathrm{C}$ was withheld. The administration of 1-ascorbic acid completely eradicated the defect without necessarily raising the plasma ascorbic acid levels. The administration of $d$ isoascorbic acid had a transient and partial effect, and the administration in large dosage, either singly or in combination, of thiamine, riboflavin, nicotinic acid, vitamin $B_{6}$, vitamin $H$, pantothenic acid, choline chloride, a-tocopherol, adrenal cortical extract, rice polishings, yeast powder and liver extract (orally) was without effect. In one of 4 infants, a crude liver extract by injection resulted in a transient but definite decrease in excretion of hydroxyphenyl compounds.

Full term infants. Full term infants fed similar diets showed no spontaneous defect in their metabolism of aromatic amino acids. The defect was precipitated by the ingestion of a single dose of 1.0 gram per $\mathrm{kgm}$. of phenylalanine in one infant and of tyrosine in another. The artificially induced defect in these subjects was readily abolished by the administration of 1-ascorbic acid and, in one infant, by the parenteral administration of whole liver extract.

\section{BIBLIOGRAPHY}

1. Levine, S. Z., Marples, E., and Gordon, H. H., A defect in the metabolism of tyrosine and phenylalanine in premature infants. I. Identification and assay of intermediary products. J. Clin. Invest., 1941, 20, 199.

2. Levine, S. Z., Discussion at the meeting of the American Pediatric Society, Skytop, Pa., April 28, 1939. Amer. J. Dis. Child., 1939, 58, 674.

3. Levine, S. Z., Marples, E., and Gordon, H. H., A defect in the metabolism of aromatic amino acids in premature infants: The role of vitamin C. Science, 1939, 90, 620.

4. Bessey, O., A method for the determination of small quantities of ascorbic acid and dehydroascorbic acid in turbid and colored solutions in the presence of other reducing substances. J. Biol. Chem., 1938, 126, 771. 
5a. Hoag, L. A., Apparatus for quantitative collection of urine and of stools in male infants. Amer. J. Dis. Child., 1932, 44, 770.

b. Gordon, H. H., and others, Respiratory metabolism in infancy and in childhood. XX. The nitrogen metabolism in premature infants; comparative studies of human milk and cow's milk. Amer J. Dis. Child., 1937, 54, 1030.

6. Folin, O., and Ciocalteu, V., On tyrosine and tryptophane determinations in proteins. J. Biol. Chem., 1927, 73, 627.

7. Medes, G., A new error of tyrosine metabolism: Tyrosinosis. The intermediary metabolism of tyrosine and phenylalanine. Biochem. J., 1932, 26, 917.

8. Mindlin, R. L., and Butler, A. M., Determination of ascorbic acid in plasma: Macromethod and micromethod. J. Biol. Chem., 1938, 122, 673.

9. Sealock, R. R., and Silberstein, H. E., The excretion of homogentisic acid and other tyrosine metabolites by the vitamin C-deficient guinea pig. J. Biol. Chem., 1940, 135, 251.

10a. Dalmer, O., and Moll, T., Zur Frage der antiskorbutischen Wirksamkeit ascorbinsäureähnlichen Verbindung. Ztschr. f. physiol. Chem., 1933, 222, 116.

b. Demole, V., On the physiological action of ascorbic acid and some related compounds. Biochem. J., 1934, 28, 770.

c. Zilva, S. S., The behavior of 1-ascorbic acid and chemically related compounds in the animal body. Antiscorbutic activity in relation to retention by the organism. Biochem. J., 1935, 29, 1612.

11a. Kajdi, L., Light, J., and Kajdi, C., Test for determination of vitamin $\mathrm{C}$ storage; vitamin $\mathrm{C}$ index. J. Pediat., 1939, 15, 197.

b. Crandon, J. H., Lund, C. C., and Dill, D. B., Experimental human scurvy. New England J. Med., 1940, 223, 353.

c. Butler, A. M., and Cushman, M., Distribution of ascorbic acid in the blood and its significance. $\mathrm{J}$. Clin. Invest., 1940, 19, 459.

12. Park, E. A., and others, The recognition of scurvy with especial reference to the early $\mathbf{x}$-ray changes. Arch. Dis. Child., 1935, 10, 265.

13a. Jackson, D., and Park, E. A., Congenital scurvy. A case report. J. Pediat., 1935, 7, 741.

b. Ingalls, T. H., Infantile scurvy. Part II. Studies on the concentration of ascorbic acid in the tissues. J. Pediat., 1939, 14, 593.

14a. Mendel, L. B., and Mitchell, P. H., Chemical studies on growth. II. The enzymes involved in purine metabolism in the embryo. Am. J. Physiol., 1907-08, 20, 97.

b. Wells, H. G., and Corper, H. J., The purines and purine metabolism of the human fetus and placenta. J. Biol. Chem., 1909, 6, 469.

15. Sealock, R. R., Galdston, M., and Steele, J. M., Administration of ascorbic acid to an alkaptonuric patient. Proc. Soc. Exper. Biol. and Med., 1940, 44, 580.

16. Jervis, G. A., Personal communication.

17a. Iob, V., and Swanson, W. W., Mineral growth of the human fetus. Amer. J. Dis. Child., 1934, 47, 302.

b. Stearns, G., The mineral metabolism of normal infants. Physiol. Rev., 1939, 19, 415.

18. Toverud, $K$. U., The vitamin $C$ content of the liver of newborn infants. Arch. Dis. Child., 1935, 10, 313.

19. Steinebrei, H., Ausmass der Vitamin C-Sättigung bei Frühgeborenen. Klin. Wchnschr., 1939, 18, 489.

20. Neuweiler, W., Vitamin C-Stoffwechsel bei Neugeborenen. Ztschr. f. Vitaminforschung, 1937, 6, 75.

21. Closs, K., and Fölling, A., Ueber die Ausscheidung von Phenylbrenztraubensäure im Harn der weissen Ratte bei Vitamin $B_{1}$-Mangel. Ztschr. f. physiol. Chem., 1938, 254, 258.

22. Snelling, C. E., Plasma ascorbic acid of infants and children. J. Pediat., 1939, 15, 824.

23a. Wolbach, S. B., and Howe, P. R., Intercellular substances in experimental scorbutus. Arch. Path. and Lab. Med., 1926, $1,1$.

b. Wolbach, S. B., Controlled formation of collagen and reticulum. A study of the source of intercellular substances in recovery from experimental scorbutus. Amer. J. Path., 1933, 9, 689. 